\title{
Pregnancy in female house mice exposed to urinary chemosignals from other females
}

\author{
L. C. Drickamer* \\ Department of Zoology, Southern Illinois University, Carbondale, IL 62901-6501, USA
}

\begin{abstract}
Seven experiments were performed to investigate pregnancy termination, urinary chemosignals, and litter sex ratio variation in female house mice. Experiments tested the effects of urine from adult and prepubertal females, housed individually or in groups, on successful insemination and litter production by females treated at different times and for different periods during the 3 weeks before mating and during gestation. Treatment of females with urine from adult females housed eight per cage or with urine pooled from eight adult females housed individually for 2 or 3 weeks before mating resulted in fewer successful pregnancies and significantly more female-biased litters. Treatment with urine from adult or prepubertal females housed eight per cage or with urine pooled from eight mice housed individually for the first 6 days of gestation or throughout pregnancy resulted in a significant increase in the rate of pregnancy termination. These treatments resulted in lower body weights at birth and slower growth rates in all males and in some females. Puberty was delayed in female progeny from urine-treated dams in five of seven experiments, and these young females attained first oestrus at greater mean body weights than mice in other treatments. These findings indicate that, in mice, at high population density, communication via a urinary chemosignal can alter reproduction in recipient females. Availability of, and competition for, resources such as food would be greater at higher densities, possibly lowering the probability of reproductive success. Pregnancy termination and delays in reproduction and attainment of sexual maturity might lead to greater successful reproduction at a later time.
\end{abstract}

\section{Introduction}

The aim of these experiments was to integrate three different factors that affect the physiology of reproduction in small mammals: (i) the pregnancy blocking effect; (ii) the influence of urinary chemosignals on reproduction; and (iii) the possibility that the condition of females influences the sex ratio of litters produced. House mice were selected for this study because of knowledge of these reproductive factors in this species.

Exposure of a recently inseminated female mouse to a strange male or odour from a strange male can result in 'pregnancy block' or termination of the pregnancy (Bruce, 1960; Parkes and Bruce, 1962; Marchlewska-Koj, 1983). The effect occurs during the first 4-6 days after insemination due to failure of implantation. The effect does not require the presence of a strange male, but occurs when the recently inseminated female mouse is exposed to urine from a strange male (Dominic, 1965). The endocrinology of this pregnancy termination effect and aspects of male chemosignal

*Current address: Department of Biological Sciences, Northern Arizona University, Flagstaff, AZ 86011-5640, USA.

Received 8 May 1998. production have been studied extensively (reviewed by Marchlewska-Koj, 1983). The effect has also been reported for other rodents, including Microtus (Clulow and Clarke, 1968; Clulow and Langford, 1971) and Peromyscus (Bronson and Eleftheriou, 1963; Bronson et al., 1969). The present study investigated whether another urinary cue from house mice, that is, urine from females housed in groups, can also induce pregnancy termination.

Urinary chemosignals influence the reproductive physiology of female house mice, including the timing of puberty in young female house mice, and reproductive cycles of adult females (Vandenbergh, 1983; Vandenbergh and Coppola, 1986; Drickamer, 1986a; Massey, 1986). Adult male urine, and urine from females that are pregnant, lactating, or in oestrus accelerate puberty in young female mice (Vandenbergh, 1969; Drickamer, 1984, 1986b). Urine from females housed in groups modulates these acceleratory chemosignal influences and results in a delay in puberty (Drickamer, 1977, 1982). Whitten (1958, 1959) showed that female house mice housed in groups often showed anoestrus. Grouping female mice can also result in oestrous cycles of different durations (Massey, 1986). These effects are a function of a urinary chemosignal (Drickamer, 1992). On the basis of the pregnancy block phenomenon and the fact 
that urine from grouped females delays puberty in young females and increases the duration of the oestrous cycle in adult females, the present study tested the hypothesis that urine from grouped females results in lower rates of pregnancy in females mated after exposure to the chemosignal.

Data from several studies and the theory of Trivers and Willard (1973) indicate that secondary sex ratios (at birth) can be influenced by maternal condition in mammals (Rivers and Crawford, 1974; Labov et al., 1986). According to Trivers and Willard (1973), females in poor condition produce more female-biased litters, while females in good condition produce more male-biased litters. Meikle and Drickamer (1986) reported that in house mice, variation in maternal nutritional status during the week before mating influenced the sex ratio of litters. Females deprived of food every other day for the week before mating had significantly more female-biased litters than control females that were not deprived of food. On the basis of these findings and those discussed earlier, the present study tested the hypothesis that the chemosignal in the urine of grouped females results in a stress on the treated female which affects the sex ratio of the progeny produced.

Two experimental series were conducted. In the first series, adult females were treated with urine from grouped females before mating. These experiments tested the effects of urine on the tendency of treated females to become pregnant. In the second series of experiments, pregnant females were treated with urine from grouped females to test the possibility that chemosignal exposure could result in pregnancy termination. In both series, the litter sex ratios and growth characteristics of the litters produced were measured to ascertain whether there were any effects of urine treatment of the dams. Finally, in accordance with the finding of Drickamer and Meikle (1988) that puberty is delayed in female progeny of food-deprived dams, age at first oestrus was determined in female progeny in each of the experiments.

\section{Materials and Methods}

\section{General methods}

The mice were second and third generation laboratory mice bred from a wild stock captured at several farms located in the area surrounding Williamstown, MA. The animals were maintained in polypropylene shoe box cages of $15 \mathrm{~cm} \times 28 \mathrm{~cm} \times 15 \mathrm{~cm}$ with opaque sides and fitted wire lids. A bedding of ground wood shavings was changed once a week. Pregnant and lactating females with young mice were provided with cotton for making nests. Wayne Lab Blox (St Louis, MO) and water were supplied ad libitum to all mice throughout the experiments. All cages were maintained in the same room at $21-25^{\circ} \mathrm{C}$ and $30-60 \%$ relative humidity on a $12 \mathrm{~h}$ light:12 h dark regimen with overhead fluorescent lights switched on from 06:00 to 18:00 h.

Two adult females aged 80-120 days were paired with fertile adult males to provide test females. Pregnant females were isolated in individual cages at least 7 days before parturition. Mice from these litters were weaned at 24 days of age. Females were housed in groups of four mice per cage until 90 days of age. At that time, they were used in the experiments described below.

In each of the seven experiments, nulliparous female mice 80-100 days of age were treated with urine from other females or water for prescribed periods of time either before mating or during pregnancy. Seven treatments were used: (i) water (as a control); (ii) urine from adult females housed eight per cage; (iii) urine from prepubertal females housed eight per cage; (iv) urine from adult females housed individually; (v) urine from prepubertal females housed individually; (vi) urine pooled from eight adult females housed individually; and (vii) urine pooled from eight prepubertal females housed individually. Littermate females were not used in the same treatment group.

Mice used for urine collection were produced in the same manner as the test females. Adult females used for urine collection were 80-130 days of age. Prepubertal females used for urine collection were 25-45 days of age. Littermate females were not housed together in the same urine production cage. Mice were housed under the conditions described for a minimum of 2 weeks before they were used for urine collection (Drickamer, 1983).

In each experiment, fresh urine was collected once a day from batteries of $12-20$ cages of donor females of the designated types. Urine was collected by holding each donor mouse over a Petri dish and gently squeezing the flanks. Urine was applied to the external nares of treatment subjects using a small paintbrush (approximately $0.05 \mathrm{ml}$ is transferred in this manner). Separate Petri dishes and paintbrushes were used for each treatment.

Male mice used for matings were from the same wild stock used to obtain the females. Pairings were made such that no female was placed with a littermate male.

The same set of dependent variables was used in each experiment: (i) the presence or absence of a litter; (ii) total litter size; (iii) the proportion of females in the birth litter; (iv) mean body weight at birth of male pups; $(\mathrm{v})$ mean body weight at birth of female pups; (vi) the proportion of pups in a litter that were weaned; (vii, viii) mean increase in body weight in males and females from birth to weaning; (ix) age at first oestrus for a female selected at random from the litter; and $(x)$ body weight at first oestrus for selected females. Litters were considered to be the independent unit for data analysis.

A female was randomly selected from each litter, weaned at 24 days of age and housed individually to test the timing of puberty. The first vaginal oestrus was determined by monitoring each test female from weaning at 24 days of age until a perforate vagina was observed and thereafter by taking vaginal lavages once a day. The wet-mount vaginal smears were examined immediately using a light microscope and the cellular content was used to determine the stage of the oestrous cycle according to the criteria of Rugh (1968) and Vandenbergh (1969). Body weight was measured to the nearest $0.1 \mathrm{~g}$ using an O'Haus beam balance.

Data on successful pregnancies were analysed using the chi-squared test (Zar, 1996). All other dependent variables were analysed using one-way ANOVA with seven treatment 
Table 1. Number of female house mice producing litters after treatment with urine before mating or during pregnancy

\begin{tabular}{lccccccc}
\hline Source of urine & Expt 1 & Expt 2 & Expt 3 & Expt 4 & Expt 5 & Expt 6 & Expt 7 \\
\hline Control (water) & 20 & 19 & 18 & 18 & 18 & 18 & 17 \\
Adult females, eight per cage & 11 & 12 & 15 & 10 & 11 & 17 & 19 \\
Prepubertal females, eight per cage & 17 & 18 & 18 & 12 & 13 & 18 & 17 \\
$\begin{array}{l}\text { Adult females, one per cage } \\
\text { Prepubertal females, one per cage }\end{array}$ & 18 & 18 & 18 & 16 & 16 & 17 & 19 \\
$\begin{array}{l}\text { Pooled from eight adult females, } \\
\text { one per cage }\end{array}$ & 11 & 13 & 14 & 12 & 12 & 18 & 16 \\
$\begin{array}{l}\text { Pooled from eight prepubertal females, } \\
\text { one per cage }\end{array}$ & 17 & 18 & 18 & 13 & 13 & 18 & 17 \\
\hline
\end{tabular}

For each treatment, $n=20$.

conditions (Zar, 1996). The initial sample size in each treatment of each experiment was $n=20$. Sample sizes in the analyses varied due to the absence of litters within some treatments and, for some variables, the absence of females or males in the litters produced by treated females. The tables of significant results are arranged in the order of the dependent variables presented above.

\section{Experiments 1-3}

The first three experiments were designed to test the effects of treating females with urine from other females before mating. In Expt 1, treatments were applied once a day for 3 weeks. All treatments were applied between 06:00 and 08:00 h. Females were then paired with an adult male for 1 week. The male was then removed and each female was monitored every day for 3 weeks for the birth of a litter.

The procedures used for Expts 2 and 3 were as described for Expt 1, with the exception that the female mice were treated with urine for 2 weeks and 1 week, respectively, before a 1 week mating period with the male.

\section{Experiments $4-7$}

The second series of experiments was designed to test the effects of the seven urine or water treatments used in Expts 1-3 on pregnant females. In these experiments, urine or water treatments were applied to females that had been mated with a male, examined every day for the presence of a vaginal plug, and separated from the male at the appearance of a plug. The day on which the vaginal plug was first observed was considered day 1. In Expt 4, urine was applied once a day to the external nares beginning on day 1 and ending on day 18 , shortly before expected parturition.

The procedure used for Expt 5 was as described for Expt 4, with the exception that pregnant females were treated only on days 1-6 after discovery of the vaginal plug. This encompassed the period before and during implantation of the embryos in the uterus.

The procedures used for Expts 6 and 7 were as described for Expt 4, with the exception that pregnant females were treated only on days $7-12$ or days $13-18$, respectively, after discovery of the vaginal plug.

\section{Results}

\section{Experiment 1}

Significantly fewer matings resulted in litters when the females were treated with urine from either adult females housed eight per cage or with urine pooled from eight adult females housed individually $\left(\chi^{2}=25.437, \mathrm{df}=6, P<0.0001\right.$; Table 1). There was a significant effect for sex ratio variation ( $F=2.198, \mathrm{df}=6,106, P=0.0488$ ). Females that had been treated with urine from adult females housed eight per cage or with urine pooled from eight adult females housed individually had significantly female-biased litters compared with control females of those that received the other urine treatments (Table 2). Female pup growth rates were significantly greater for litters born to females that had been treated with water or with urine from adult females housed eight per cage ( $F=2.514$, $\mathrm{df}=6,93, P=0.0267$; Table 3 ).

There were significant differences in age at first oestrus $(F=30.454 ; \mathrm{df}=6,94, P<0.0001 ;$ Table 4$)$ and body weight at first oestrus ( $F=16.838, \mathrm{df}=6,94, P<0.0001$; Table 5 ) for the randomly selected female progeny born to animals treated with urine from adult females housed eight per cage or from eight adult females housed individually. None of the other dependent variables results in significant $F$ ratios from ANOVA.

\section{Experiment 2}

Significantly fewer matings resulted in litters when females were treated with urine from either adult females housed eight per cage or with urine pooled from eight adult females housed individually $\left(\chi^{2}=15.610, \mathrm{df}=6, P<0.025\right.$; Table 1). There was a significant effect for sex ratio variation ( $F=4.032$, df $=6,109, P=0.0011$ ). Females that had been treated with urine from adult females housed eight per cage or with urine pooled from eight adult females housed individually had significantly female-biased litters compared with control females or those that received the other urine treatments (Table 2).

In male pups, both mean body weight at birth $(F=3.216$; $\mathrm{df}=6,108, P=0.0061$; Table 6) and mean growth rate $(F=1.302, \quad \mathrm{df}=6,97, \quad P=0.0026$; Table 7$)$ resulted in significant $F$ ratio statistics. Male progeny born to females 
Table 2. Proportion (\%) of female pups in litters of house mice born to females treated with urine before mating in three experiments in which the overall $F$ ratio was significant

\begin{tabular}{lccc}
\hline Source of urine & Expt 1 & Expt 2 & Expt 3 \\
\hline Control (water) & $47.3(4.3)^{\mathrm{a}}$ & $42.7(4.1)^{\mathrm{a}}$ & $44.4(5.3)^{\mathrm{a}}$ \\
Adult females, eight per cage & $66.9(5.3)^{\mathrm{b}}$ & $62.9(5.4)^{\mathrm{b}}$ & $55.4(4.3)^{\mathrm{b}}$ \\
Prepubertal females, eight per cage & $46.5(5.5)^{\mathrm{a}}$ & $44.2(5.1)^{\mathrm{a}}$ & $41.2(3.6)^{\mathrm{a}}$ \\
Adult females, one per cage & $48.0(5.1)^{\mathrm{a}}$ & $45.1(4.9)^{\mathrm{a}}$ & $43.5(3.7)^{\mathrm{a}}$ \\
Prepubertal females, one per cage & $47.9(5.1)^{\mathrm{a}}$ & $43.4(4.5)^{\mathrm{a}}$ & $40.7(5.4)^{\mathrm{a}}$ \\
Pooled from eight adult females, one per cage & $63.5(5.1)^{\mathrm{b}}$ & $67.1(3.2)^{\mathrm{b}}$ & $62.0(5.9)^{\mathrm{b}}$ \\
Pooled from eight prepubertal females, one per cage & $48.5(4.9)^{\mathrm{a}}$ & $45.9(4.4)^{\mathrm{a}}$ & $42.6(4.7)^{\mathrm{a}}$ \\
\hline
\end{tabular}

Values are mean \pm SEM

Values within columns with different letters are significantly different $(P<0.05$, Tukey's $w$ procedure; Steel and Torrie, 1960$)$.

Table 3. Increase in body weight between birth and weaning of female house mice pups born to females treated with urine before mating or during pregnancy in experiments in which there was a significant $F$ ratio

\begin{tabular}{lccc}
\hline & \multicolumn{3}{c}{ Increase in body weight (g) } \\
\cline { 2 - 4 } Source of urine & Expt 1 & Expt 4 & Expt 5 \\
\hline Control (water) & $5.3(0.1)^{\mathrm{b}}$ & $5.2(0.2)^{\mathrm{b}}$ & $5.2(0.1)^{\mathrm{b}}$ \\
Adult females, eight per cage & $5.3(0.3)^{\mathrm{b}}$ & $4.5(0.2)^{\mathrm{a}}$ & $4.2(0.1)^{\mathrm{a}}$ \\
Prepubertal females, eight per cage & $4.8(0.1)^{\mathrm{a}}$ & $4.5(0.1)^{\mathrm{a}}$ & $4.0(0.1)^{\mathrm{a}}$ \\
Adult females, one per cage & $4.9(0.2)^{\mathrm{a}}$ & $4.9(0.1)^{\mathrm{ab}}$ & $5.1(0.1)^{\mathrm{b}}$ \\
Prepubertal females, one per cage & $4.8(0.1)^{\mathrm{a}}$ & $5.2(0.1)^{\mathrm{b}}$ & $5.2(0.1)^{\mathrm{b}}$ \\
Pooled from eight adult females, one per cage & $4.7(0.3)^{\mathrm{d}}$ & $4.5(0.1)^{\mathrm{a}}$ & $3.9(0.1)^{\mathrm{a}}$ \\
Pooled from eight prepubertal females, one per cage & $4.7(0.1)^{\mathrm{a}}$ & $4.5(0.1)^{\mathrm{a}}$ & $4.0(0.1)^{\mathrm{a}}$ \\
\hline
\end{tabular}

Values are mean \pm SEM.

Values within columns without a common letter are significantly different $(P<0.05$, Tukey's $w$ procedure; Steel and Torrie, 1960$)$.

Table 4. Age at first oestrus of female house mice born to females treated with urine before mating or during pregnancy in experiments in which there was a significant $F$ ratio

\begin{tabular}{|c|c|c|c|c|c|}
\hline \multirow[b]{2}{*}{ Source of urine } & \multicolumn{5}{|c|}{ Age (days) } \\
\hline & Expt 1 & Expt 2 & Expt 3 & Expt 4 & Expt 5 \\
\hline Control (water) & $53.8(1.3)^{\mathrm{a}}$ & $54.7(0.9)^{\mathrm{a}}$ & $54.8(1.1)^{\mathrm{a}}$ & $54.9(0.8)^{\mathrm{a}}$ & $55.5(0.8)^{a}$ \\
\hline Adult females, eight per cage & $67.9(1.5)^{\mathrm{b}}$ & $65.3(1.3)^{b}$ & $58.8(1.2)^{b}$ & $64.7(1.1)^{\mathrm{b}}$ & $64.4(1.1)^{\mathrm{b}}$ \\
\hline Prepubertal females, eight per cage & $54.2(1.1)^{\mathrm{a}}$ & $54.8(1.0)^{\mathrm{a}}$ & $55.1(0.9)^{\mathrm{a}}$ & $64.5(1.2)^{\mathrm{b}}$ & $64.7(1.1)^{\mathrm{b}}$ \\
\hline Adult females, one per cage & $55.2(0.9)^{a}$ & $53.8(0.8)^{\mathrm{a}}$ & $54.5(1.0)^{\mathrm{a}}$ & $54.6(0.9)^{\mathrm{a}}$ & $55.3(1.2)^{\mathrm{a}}$ \\
\hline Prepubertal females, one per cage & $54.3(0.8)^{\mathrm{a}}$ & $54.4(0.9)^{\mathrm{a}}$ & $55.3(0.8)^{\mathrm{a}}$ & $54.8(0.9)^{\mathrm{a}}$ & $55.6(0.9)^{2}$ \\
\hline $\begin{array}{l}\text { Pooled from eight adult females, } \\
\text { one per cage }\end{array}$ & $69.1(1.5)^{b}$ & $66.1(1.2)^{\mathrm{b}}$ & $58.3(1.3)^{\mathrm{b}}$ & $64.2(0.8)^{\mathrm{b}}$ & $63.9(1.1)^{\mathrm{b}}$ \\
\hline $\begin{array}{l}\text { Pooled from eight prepubertal females, } \\
\text { one per cage }\end{array}$ & $54.5(1.0)^{\mathrm{a}}$ & $54.3(0.8)^{\mathrm{a}}$ & $54.2(0.8)^{\mathrm{a}}$ & $65.1(0.8)^{\mathrm{b}}$ & $64.2(1.0)^{\mathrm{b}}$ \\
\hline
\end{tabular}

Values are mean \pm SEM.

Values within columns with different letters are significantly different $(P<0.05$, Tukey's $w$ procedure; Steel and Torrie, 1960$)$.

that were treated with urine from adult females housed eight per cage had significantly greater body weights at birth than those born to females that were treated with pooled urine from eight prepubertal females housed individually. The other treatments resulted in intermediate mean pup body weights at birth (Table 6). There was a complex pattern of overlapping significant differences in mean growth from birth to weaning in male pups (Table 7).
There were significant differences in age at first oestrus $(F=29.012, \mathrm{df}=6,95, P<0.0001$; Table 4$)$ and body weight at first oestrus $(F=10.535, \mathrm{df}=6,95, P<0.0001$; Table 5$)$ for the randomly selected female progeny born to animals treated with urine from either adult females housed eight per cage or from eight adult females housed individually. None of the other dependent variables results in significant $F$ ratios from ANOVA. 
Table 5. Body weight at first oestrus of female house mice born to females treated with urine before mating or during pregnancy in experiments in which there was a significant $F$ ratio

\begin{tabular}{lccccc}
\hline & \multicolumn{5}{c}{ Body weight (g) } \\
\cline { 2 - 6 } Source of urine & Expt 1 & Expt 2 & Expt 3 & Expt 4 & Expt 5 \\
\hline Control (water) & $13.7(0.2)^{\mathrm{a}}$ & $13.4(0.3)^{\mathrm{a}}$ & $13.8(0.2)^{\mathrm{ab}}$ & $13.1(0.1)^{\mathrm{a}}$ & $13.6(0.2)^{\mathrm{a}}$ \\
Adult females, eight per cage & $15.5(0.3)^{\mathrm{b}}$ & $14.9(0.2)^{\mathrm{b}}$ & $14.6(0.3)^{\mathrm{b}}$ & $13.9(0.2)^{\mathrm{b}}$ & $15.1(0.1)^{\mathrm{b}}$ \\
Prepubertal females, eight per cage & $13.9(0.1)^{\mathrm{a}}$ & $13.7(0.2)^{\mathrm{a}}$ & $13.5(0.3)^{\mathrm{a}}$ & $14.1(0.2)^{\mathrm{b}}$ & $15.3(0.1)^{\mathrm{b}}$ \\
$\begin{array}{l}\text { Adult females, one per cage } \\
\text { Prepubertal females, one per cage }\end{array}$ & $13.9(0.2)^{\mathrm{a}}$ & $13.3(0.2)^{\mathrm{a}}$ & $13.1(0.2)^{\mathrm{a}}$ & $13.3(0.2)^{\mathrm{a}}$ & $13.6(0.1)^{\mathrm{a}}$ \\
$\begin{array}{l}\text { Pooled from eight adult females, } \\
\text { one per cage }\end{array}$ & $15.4(0.1)^{\mathrm{a}}$ & $13.4(0.2)^{\mathrm{a}}$ & $13.6(0.2)^{\mathrm{ab}}$ & $13.5(0.2)^{\mathrm{a}}$ & $13.6(0.1)^{\mathrm{a}}$ \\
$\begin{array}{l}\text { Pooled from eight prepubertal females, } \\
\text { one per cage }\end{array}$ & $13.7(0.2)^{\mathrm{a}}$ & $14.6(0.2)^{\mathrm{b}}$ & $14.2(0.3)^{\mathrm{b}}$ & $14.7(0.1)^{\mathrm{b}}$ & $14.8(0.2)^{\mathrm{b}}$ \\
\hline
\end{tabular}

Values are mean \pm SEM.

Values within columns without a common letter are significantly different $(P<0.05$, Tukey's $w$ procedure; Steel and Torrie, 1960$)$.

Table 6. Birth weights (g) of male and female house mice pups born to females treated with urine before mating or during pregnancy in experiments in which there was an overall significant $F$ ratio

\begin{tabular}{lccccc}
\hline & \multicolumn{2}{c}{ Males } & & \multicolumn{2}{c}{ Females } \\
\cline { 2 - 3 } \cline { 5 - 6 } Source of urine & Expt 2 & Expt 3 & & Expt 4 & Expt 5 \\
\hline Control (water) & $1.8(0.1)^{\mathrm{ab}}$ & $1.6(0.1)^{\mathrm{ab}}$ & & $1.7(0.1)^{\mathrm{b}}$ & $1.7(0.1)^{\mathrm{b}}$ \\
Adult females, eight per cage & $1.8(0.1)^{\mathrm{ab}}$ & $1.4(0.1)^{\mathrm{a}}$ & & $1.5(0.1)^{\mathrm{ab}}$ & $1.4(0.1)^{\mathrm{a}}$ \\
Prepubertal females, eight per cage & $1.7(0.1)^{\mathrm{ab}}$ & $1.4(0.1)^{\mathrm{a}}$ & & $1.5(0.1)^{\mathrm{ab}}$ & $1.4(0.1)^{\mathrm{a}}$ \\
Adult females, one per cage & $1.6(0.1)^{\mathrm{ab}}$ & $1.7(0.1)^{\mathrm{b}}$ & & $1.7(0.1)^{\mathrm{b}}$ & $1.7(0.1)^{\mathrm{b}}$ \\
$\begin{array}{l}\text { Prepubertal females, one per cage } \\
\text { Pooled from eight adult females, }\end{array}$ & $1.7(0.1)^{\mathrm{ab}}$ & $1.7(0.1)^{\mathrm{b}}$ & & $1.7(0.1)^{\mathrm{b}}$ & $1.7(0.1)^{\mathrm{b}}$ \\
$\begin{array}{l}\text { one per cage } \\
\text { Pooled from eight prepubertal females, }\end{array}$ & $1.6(0.1)^{\mathrm{ab}}$ & $1.4(0.1)^{\mathrm{a}}$ & & $1.5(0.1)^{\mathrm{ab}}$ & $1.4(0.1)^{\mathrm{a}}$ \\
\begin{tabular}{l} 
one per cage \\
\hline
\end{tabular} & $1.5(0.1)^{\mathrm{a}}$ & $1.5(0.1)^{\mathrm{ab}}$ & & $1.4(0.1)^{\mathrm{a}}$ & $1.4(0.1)^{\mathrm{a}}$ \\
\hline
\end{tabular}

Values are mean \pm SEM.

Values within columns without a common letter are significantly different $(P<0.05$, Tukey's $w$ procedure; Steel and Torrie, 1960$)$.

Table 7. Increase in body weight between birth and weaning of male house mice pups born to females treated with urine before mating or during pregnancy in experiments in which there was a significant $F$ ratio

\begin{tabular}{lcccc}
\hline & \multicolumn{3}{c}{ Increase in body weight $(\mathrm{g})$} \\
\cline { 2 - 5 } Source of urine & Expt 2 & Expt 3 & Expt 4 & Expt 5 \\
\hline Control (water) & $5.5(0.2)^{\mathrm{c}}$ & $5.5(0.2)^{\mathrm{c}}$ & $5.7(0.2)^{\mathrm{c}}$ & $5.5(0.1)^{\mathrm{b}}$ \\
Adult females, eight per cage & $4.9(0.1)^{\mathrm{ab}}$ & $5.4(0.2)^{\mathrm{c}}$ & $4.6(0.2)^{\mathrm{a}}$ & $4.5(0.1)^{\mathrm{a}}$ \\
Prepubertal females, eight per cage & $5.1(0.1)^{\mathrm{bc}}$ & $5.0(0.2)^{\mathrm{bc}}$ & $4.4(0.2)^{\mathrm{a}}$ & $4.3(0.1)^{\mathrm{a}}$ \\
$\begin{array}{l}\text { Adult females, one per cage } \\
\text { Prepubertal females, one per cage }\end{array}$ & $5.2(0.1)^{\mathrm{c}}$ & $5.0(0.2)^{\mathrm{bc}}$ & $4.9(0.2)^{\mathrm{ab}}$ & $5.5(0.2)^{\mathrm{b}}$ \\
$\begin{array}{l}\text { Pooled from eight adult females, } \\
\text { one per cage }\end{array}$ & $4.6(0.2)^{\mathrm{a}}$ & $4.8(0.2)^{\mathrm{ab}}$ & $5.3(0.1)^{\mathrm{bc}}$ & $5.5(0.1)^{\mathrm{b}}$ \\
$\begin{array}{l}\text { Pooled from eight prepubertal females, } \\
\text { one per cage }\end{array}$ & $5.0(0.1)^{\mathrm{bc}}$ & $4.8(0.3)^{\mathrm{ab}}$ & $4.7(0.2)^{\mathrm{a}}$ & $4.2(0.1)^{\mathrm{a}}$ \\
\hline
\end{tabular}

Values are mean \pm SEM

Values within columns without a common letter are significantly different $(P<0.05$, Tukey's $w$ procedure; Steel and Torrie, 1960$)$.

\section{Experiment 3}

There was no significant effect with respect to the number of females in the different treatments producing litters $\left(\chi^{2}=8.409, \mathrm{df}=6,0.10<P<0.30\right.$; Table 1$)$. There was a significant effect for sex ratio variation $(F=2.676, \mathrm{df}=6,113$, $P=0.0182)$. Females that had been treated with urine from adult females housed eight per cage or with urine pooled from eight adult females housed individually had significantly female-biased litters compared with control females of those that received the other urine treatments (Table 2).

There was a significant overall effect with regard to growth from birth to weaning in male pups $(F=2.708$, $\mathrm{df}=6,101, P=0.0176$ ). The significant differences (Table 7) among the means showed a complex overlapping pattern. 
There were significant differences in age at first oestrus ( $F=3.326, \mathrm{df}=6,102, P=0.0049$; Table 4$)$ and for body weight at first oestrus $(F=3.122, \mathrm{df}=6,102, P=0.0075$; Table 5$)$ for the randomly selected female progeny born to animals treated with urine from either adult females housed eight per cage or from eight adult females housed individually. None of the other dependent variables result in significant $F$ ratios from ANOVA.

\section{Experiment 4}

Significantly fewer matings resulted in litters when females were treated with urine from either adult or prepubertal females housed eight per cage or with urine pooled from eight adult or prepubertal females housed individually $\left(\chi^{2}=13.430\right.$, $\mathrm{df}=6, P<0.05$; Table 1). In male pups, there were significant differences in mean body weights at birth $(F=10.838, \mathrm{df}=6,88$, $P<0.001$; Table 6). Male progeny had significantly lower body weights when females were treated with urine from adult or prepubertal females housed eight per cage or with urine from eight adult females housed individually, than when females were given one of the other four treatments.

There were significant effects for growth between birth and weaning in males $(F=9.918, \mathrm{df}=6,80, P<0.001$; Table 7$)$ and females $(F=7.664, \mathrm{df}=6,80, P<0.001$; Table 3$)$. Males tended to grow more slowly when their mothers had been treated with urine from adult or prepubertal females housed either eight per cage or with the urine pooled from eight mice housed individually than when their mothers had been given one of the other three treatments. However, there was some overlap for the group of pregnant females treated with urine from adult females housed individually, and male progeny of control females increased in weight at a greater rate than all other groups except the group of pregnant females treated with urine from prepubertal females housed one per cage (Table 7). In female progeny, growth was slower in the four treatments involving treatment of pregnant females with urine from adult or prepubertal females housed eight per cage or treatment with pooled urine from adult or prepubertal females housed individually than for the other treatments (Table 3). Treatment with urine from adult females housed individually resulted in an intermediate mean growth rate in female progeny.

Age at first oestrus $(F=30.175, \mathrm{df}=6,80, P<0.001$; Table 4 ) and mean body weight at first oestrus $(F=14.487, \mathrm{df}=6,80$, $P<0.001$; Table 5) were significantly different among the seven treatments. In each case, the significant differences resulted from greater mean ages and higher mean body weights at first oestrus in female progeny born to females treated during pregnancy with urine from adult or prepubertal females housed eight per cage or with pooled urine from eight adult or prepubertal females housed individually (Tables 4 and 5). None of the other dependent variables result in significant $F$ ratios from ANOVA.

\section{Experiment 5}

Significantly fewer matings resulted in litters when females were treated with urine from either adult females housed eight per cage or with urine pooled from eight females housed individually $\left(\chi^{2}=17.361, \mathrm{df}=6, P<0.005\right.$; Table 1). There were significant differences in body weight at birth in both males $(F=14.004, \mathrm{df}=6,91, P<0,001$; Table 6) and females $(F=14.312, \mathrm{df}=6,94, P<0.001$; Table 6). Male progeny born to females treated with urine pooled from prepubertal females housed individually had significantly lower body weights at birth than males born to control females or those treated with urine from adult or prepubertal females housed individually. The remaining three treatments resulted in intermediate mean body weights at birth (Table 6). Female pups born to mothers that had been treated during pregnancy with urine from adult or prepubertal females housed eight per cage or with urine pooled from eight adult or prepubertal females housed individually had significantly lower body weights at birth than pups from the other three treatments (Table 6).

In male pups, mean growth between birth and weaning ( $F=30.246$, df $=6,85, P<0.001$ ) was lower for treatments involving urine from adult or prepubertal females housed eight per cage or urine pooled from eight adult or prepubertal females housed individually than for pups from the other three treatments (Table 7). A similar significant effect was recorded for growth of female pups ( $F=37.385$, df $=6,88, P<0.001)$ in which the same pattern of significant differences among the means was observed (Table 3 ).

Age at first oestrus $(F=21.762, \mathrm{df}=6,88, \quad P<0.001$; Table 4) and mean body weight at first oestrus $(F=29.135$, $\mathrm{df}=6,88, P<0.001$; Table 5) were significantly different among the seven treatments. In each case, the significant differences resulted from greater mean ages and higher mean body weights at first oestrus in female progeny born to females treated during pregnancy with urine from adult or prepubertal females housed eight per cage or with pooled urine from eight adult or prepubertal females housed individually (Tables 4 and 5). None of the other dependent variables result in significant $F$ ratios from ANOVA.

\section{Experiment 6}

The various urine treatments had no significant effects on the numbers of females that successfully produced litters $\left(\chi^{2}=1.493, \mathrm{df}=6, P>0.50\right.$; Table 1$)$. There were no significant $F$ ratio statistics for any of the other dependent variables tested.

\section{Experiment 7}

The various urine treatments had no significant effects on the numbers of females that successfully produced litters $\left(\chi^{2}=3.445, \mathrm{df}=6, P>0.50\right.$; Table 1$)$. There were no significant $F$ ratio statistics for any of the other dependent variables tested.

\section{Discussion}

Data and analyses from Expts 1-3 lead to several conclusions. Treatment of females housed individually with urine from adult females housed eight per cage or with urine 
pooled from eight adult females housed individually for 2 or 3 weeks before mating results in significantly fewer successful pregnancies than in other treatments. In all three experiments, dams exposed to these urine treatments produced significantly more female-biased litters than in the other treatments. Furthermore, age at first vaginal oestrus was greater in mice born to females treated with urine from grouped adult females or pooled urine from adult females than in the other treatments.

These findings indicate that urine from adult females is perceived by a recipient female to be from mice living at high population density, and this results in disruption of some aspect of the oestrous cycle, mating, insemination, fertilization or implantation. This effect is only observed in treatment with urine from adult females; urine from prepubertal females housed in groups and urine pooled from prepubertal females housed individually did not affect the number of successful pregnancies compared with controls. Urine treatments involving females housed individually did not produce any effects compared with controls. The finding that treatment for 1 week before mating did not produce any effect indicates that the pheromonal stimulation was not of sufficient duration to produce any effect on pregnancy rate.

These findings may result from a mechanism similar to that reported by Massey (1986), in which females housed in groups that exhibited longer oestrous cycles produced fewer litters than females with shorter cycles. The duration of the oestrous cycle of test subjects housed individually was not tested in the present study. Therefore, it is not possible to confirm that females that were successfully inseminated were those with shorter oestrous cycles and those that did not become pregnant had cycles of greater duration, or were perhaps in anoestrus.

The results from the treatment with urine pooled from eight adult females housed individually is similar to the delay in puberty produced by urine pooled from eight adult females (Drickamer, 1982). It is possible that the same urinary chemosignal may be involved. However, urine from grouped prepubertal females also delays puberty (Drickamer, 1988). Since there was no effect on the occurrence of successful pregnancies in the current study when the urine from prepubertal females was used, this indicates that a different chemosignal or mechanism is involved. Further studies are required to confirm the difference in the effect of urine from adult versus prepubertal females and to determine any differences in the chemosignals between young and adult females.

Meikle and Drickamer (1986) reported that female mice in relatively poor condition, defined as food deprivation every other day for 1 week before mating, produced significantly more female-biased litters than controls fed ad libitum or females deprived of food every other day for 2 weeks before mating. In the present study, females treated for 2 or 3 weeks before mating, but not for 1 week, with urine from adult females housed eight per cage or with urine pooled from eight adult females produced significantly more femalebiased litters than in the other treatments. This implies that exposure for $\geq 2$ weeks to a urinary chemosignal that is perceived as indicating a high population density of other adult females leads to a shift in sex ratio. Meikle and
Drickamer (1986) reported that mice deprived of food for 2 weeks adjusted to the treatment, because they no longer produced a disproportionate number of female-biased litters. In the present study, urine treatment for 1 week did not have any effect. Further tests on the reproductive physiology of the house mice and a better understanding of the mechanism for the shifts in litter sex ratio would clarify whether there is any similarity between the manner in which food deprivation and urinary chemosignals result in changes in litter sex ratios.

The evolutionary explanation for the shift in litter sex ratio may be that when conditions are relatively poor, a dam is better off producing more of the sex, in this instance females, that have a higher likelihood of succeeding in producing at least some progeny. Since house mice are polygynous, males normally have a higher variance in reproductive success and thus would not be such a good investment when conditions are poor. In this study, the condition of high population density, represented by those treatments with urine from grouped adult females or urine pooled from adult females, indicates that increased competition for resources such as food may lead to an increase in female-biased litters.

The delayed first oestrus in offspring of females treated before mating with urine from grouped adult females or urine pooled from eight adult females is similar to the effect reported by Drickamer and Meikle (1988). They reported that age at first oestrus in female progeny of dams deprived of food during the week before mating or during the first week of pregnancy was delayed compared with controls fed ad libitum. In that study and in the present investigation, treatment of dams before mating affected the sexual development of their progeny. Therefore, it is possible that if conditions for reproduction are poor, the timing mechanism for the onset of puberty in female progeny is affected via a signal transmitted from the mother in utero. Alternatively, a signal may be transmitted in the milk during nursing; this possibility could be tested by treating lactating females with urine.

The delay in puberty observed in the present study makes sense in evolutionary terms if the young maturing females potentially waste energy by attempting to reproduce at the normal age. In the present study, dams were exposed to a stimulus, urine from grouped adult females or with urine pooled from adult females, which signified that population density, and thus competition for resources, was high. By delaying puberty for a few weeks, the body weight, and thus reserves, of the young females increase, and they can attempt to reproduce with a higher probability of success.

The significant effects obtained for body weight at birth in Expt 2 and growth rate in Expts 2 and 3 are difficult to explain. Examination of the patterns of significant differences between means provides no clues in terms of which treatments produced these effects relative to other treatments.

Data and analyses from Expts 4-7 lead to several conclusions. A significant proportion of pregnancies were terminated when recently inseminated dams were treated during pregnancy or for the 6 days after insemination with urine from four sources. The urine was from young or adult females housed eight per cage or pooled from eight young or adult animals. None of the urine treatments during gestation 
resulted in changes in litter sex ratios. In several experiments, the urine treatments that resulted in a significant increase in pregnancy termination also resulted in smaller body weights at birth and lower growth rates in male progeny. This was also observed in female progeny in one experiment. In Expts 4 and 5, the four urine treatments that resulted in an increase in the rate of pregnancy termination also resulted in a delay in puberty in female progeny, as measured by first vaginal oestrus.

The pregnancy block produced by the presence or odour of a strange male has been interpreted as a mechanism for males to increase opportunities for mating and reproductive success (Marchlewska-Koj, 1983). The magnitude of the effect is lower in female-induced pregnancy termination (40-50\% do not produce litters) than in male-induced pregnancy termination (approximately $80 \%$ do not produce litters). It is possible that pregnancy termination due to a urinary chemosignal from other females results from the stress of sensing that density is high and that there may be increased competition for resources and decreased probability of reproductive success. Additional studies are required to confirm this effect and to determine the possible underlying mechanism. In Expt 5, pregnancy termination resulting from treatment with urine from females occurred during the preimplantation period, during the first 6 days after insemination. This indicates that there is similarity between pregnancy termination induced by strange males and that induced by urine from females. In both instances, the underlying process appears to involve a physiological mechanism that involves interference with the implantation process. The roles of a number of hormones in the mechanism of pregnancy termination resulting from exposure to a strange male have been investigated for house mice (Snyder and Taggart, 1967) and deer mice (Peromyscus maniculatus bairdi; Bronson, 1968; Bronson et al., 1969).

It is interesting to speculate whether the diminution or cessation of reproduction observed in populations of other rodents, including deermice (Terman, 1965, 1987) and rats (Rattus norvegicus; Calhoun, 1957), may be explained, at least in part, by pregnancy termination due to urinary chemosignals from other females. In these studies, reproduction decreased or ceased when population densities reached various levels. Since termination of pregnancy via a signal from other females occurs early in gestation, it would be difficult to detect such pregnancies before termination.

The lack of any effect on litter sex ratio in the second series of experiments (Expts 4-7) is unexpected. Termination of pregnancy apparently occurs during preimplantation, at which time a shift in sex ratio can occur. If, as Expts 1-3 indicated, females treated with urine before mating have more female-biased litters, the same result would be expected in females treated with urine during early pregnancy. The reason for this discrepancy remains to be elucidated.

Body weight and growth effects in all male and in some female progeny in the treatments in which pregnancy termination occurred indicate that the females are affected in terms of both gestational investment and lactational investment in their progeny. Low body weight at birth and slow growth rate in progeny may be due to the physiological condition of the female. The reason for this differential effect, that male progeny are more affected than female progeny, is open to further study. It may be due to the fact that female progeny have greater probability of reproductive success than males.

Females exposed to those treatments that resulted in an increase in the rate of pregnancy termination produced female progeny that showed a delay in reaching puberty. As for Expts 1-3, it is possible that the mechanism of this delay is related to resource conditions. Higher population density implies increased competition for resources. Therefore, delaying puberty by a few weeks to attain greater body weight before attempting to reproduce may lead to more successful reproduction.

The findings of the present study provide further insight into the conflict and aggression among breeding female house mice (Parmigiani et al., 1988; Brain and Parmigiani, 1990). Much of the literature on this subject deals with postpartum encounters with familiar versus strange intruders, and the probability of infanticide. However, from the results of the present study, it is possible to speculate that encounters with conspecific females, as well as with conspecific males, also have consequences for the reproduction of females. The data presented here indicate that exposure to urinary chemosignals from grouped females impacts negatively on pregnancy. Therefore, it is proposed that pregnant females will avoid exposure to urine from grouped females in the same way as they avoid exposure to urine from strange males (Drickamer, 1989). This hypothesis remains to be tested. The results of the present study also help to explain the suppression of reproduction in one member of a pair of female house mice when the two females are unfamiliar with one another (König, 1994).

This research was supported by US Public Health Service Grant Award No. HD-08585 and by National Science Foundation Award No. BNS-8516331. The author thanks Williams College for providing the facilities and animal care support personnel. Two anonymous reviewers provided helpful comments.

\section{References}

Brain PF and Parmigiani S (1990) Variation in aggressiveness in house mouse populations Biological fournal of the Linnean Society 41 257-269

Bronson FH (1968) Pheromonal influences on mammalian reproduction. In Reproduction and Sexual Behaviour pp 341-361 Ed. M. Diamond. Indianian University Press, Bloomington, IN

Bronson FH and Eleftheriou BE (1963) Influence of strange males on implantation in deermice General and Comparative Endocrinology 3 515-518

Bronson FH, Eleftheriou BE and Dezell HE (1969) Strange male pregnancy block in deermice: prolactin and adrenocortical hormones Biology of Reproduction 1302-306

Bruce HM (1960) A block to pregnancy in the mouse caused by proximity of strange males Journal of Reproduction and Fertility 196-103

Calhoun JB (1957) A behavioral sink. In Roots of Behavior pp 295-315 Ed. EL Bliss. Harper \& Brothers, New York

Clulow FV and Clarke JR (1968) Pregnancy-block in Microtus agrestis, an induced ovulator Nature 219511

Clulow FV and Langford PE (1971) Pregnancy-block in the meadow vole, Microtus pennsylvanicus. Journal of Reproduction and Fertility 24 275-277

Dominic CJ (1965) The origin of the pheromones causing pregnancy block in mice Journal of Reproduction and Fertility 10 469-472

Drickamer LC (1977) Delay of sexual maturation in female house mice by Downloaded from Bioscientifica.com at 04/26/2023 06:19:35AM 
exposure to grouped females or urine from grouped females Journal of Reproduction and Fertility 51 77-81

Drickamer LC (1982) Delay and acceleration of puberty in female mice by urinary chemosignals from other females Developmental Psychobiology 15 $433-442$

Drickamer LC (1983) Effect of period of grouping donors and duration of stimulus exposure on delay of puberty in female mice by a urinary chemosignal from grouped females Journal of Reproduction and Fertility 69 723-727

Drickamer LC (1984) Acceleration of puberty by a urinary chemosignal from pregnant and lactating Mus musculus. Journal of Manmalogy 65 697-699

Drickamer LC (1986a) Puberty-influencing chemosignals in mice: ecological and evolutionary considerations. In Chemical Signals in Vertebrates IV pp 441-455 Eds D Duvall, D Müller-Schwarze and RM Silverstein. Plenum Publishing, New York

Drickamer LC (1986b) Effects of urine from females in oestrus on puberty in female mice fournal of Reproduction and Fertility 77 613-622

Drickamer LC (1988) Effects of age of donors on urinary chemosignals that influence the timing of first oestrus in young female house mice, Mus musculus. Journal of Reproduction and Fertility 83 829-834

Drickamer LC (1989) Pregnancy block in wild house mice, Mus domesticus: olfactory preferences of females during gestation Animal Behaviour 37 690-692

Drickamer LC (1992) Chemosignals and reproduction in adult female house mice. In Chemical Signals in Vertebrates VI pp 245-251 Eds RL Doty and D Müller-Schwarze. Plenum Publishing, New York

Drickamer LC and Meikle DB (1988) Food deprivation affects reproduction in adult female mice (Mus musculus) and the age of puberty for their female progeny Acta Biologica Hungarica 39 361-375

König B (1994) Fitness effects of communal rearing in house mice: the role of relatedness versus familiarity Animal Behaviour 48 1449-1557

Labov JB, Huck UW, Vaswani P and Lisk RD (1986) Sex ratio manipulation and decreased growth of male offspring of undernourished golden hamsters (Mesocricetus auratus) Behavioral Ecology and Sociobiology 18 241-249

Marchlewska-Koj A (1983) Pregnancy blocking by pheromones. In Pheromones and Reproduction in Mammals pp 151-174 Ed. JG Vandenbergh. Academic Press, New York
Massey A (1986) Variable responses to high density of female Mus musculus: a merger of two population regulation hypotheses Oecologia 69 140-143

Meikle DB and Drickamer LC (1986) Food availability and secondary sex ratio variation in wild and laboratory house mice (Mus musculus) Journal of Reproduction and Fertility 78 587-591

Parkes AS and Bruce HM (1962) Pregnancy-block in female mice placed in boxes soiled by males Journal of Reproduction and Fertility 4 303-308

Parmiginai S, Brain PF, Mainardi D and Brunoni V (1988) Different patterns of biting attack employed by lactating female mice (Mus domesticus) in encounters with male and female conspecific intruders Journal of Comparative Psychology 102 287-293

Rivers JPW and Crawford MA (1974) Maternal nutrition and sex ratio at birth Nature 252 297-298

Rugh R (1968) The Mouse: Its Reproduction and Development Burgess, Minneapolis

Snyder RL and Taggart NE (1967) Effects of adrenalectomy on male-induced pregnancy block in mice fournal of Reproduction and Fertility 14 451-455

Steel RGD and Torrie JH (1960) Principles and Procedures of Statistics McGrawHill, New York

Terman CR (1965) A study of population growth and control exhibited in the laboratory by prairie deermice Ecology 46 890-895

Terman CR (1987) Intrinsic behavioral and physiological differences among laboratory populations of prairie deermice American Zoologist 27 853-856

Trivers RL and Willard DE (1973) Natural selection and parental ability to vary the sex of offspring Science 179 90-92

Vandenbergh JG (1969) Male odor accelerates female sexual maturation in mice Endocrinology 84 658-660

Vandenbergh JG (1983) Pheromonal regulation of puberty. In Pheromones and Reproduction in Mammals pp 95-112 Ed. JG Vandenbergh. Academic Press, New York

Vandenbergh JG and Coppola DM (1986) The physiology and ecology of puberty modulation by primer pheromones Advances in the Study of Behavior 16 71-107

Whitten WK (1958) Modification of the oestrous cycle of the mouse by external stimuli associated with the male Journal of Endocrinology 17 307-313

Whitten WK (1959) Occurrence of anoestrus in mice caged in groups Journal of Endocrinology 18 102-107

Zar JH (1996) Biostatistical Analysis 3rd Edn Prentice Hall, Upper Saddle River, NJ 